\title{
GGE-Biplot Analysis for the Suitability of Soybean Varieties in an Agroforestry System based on Kayu Putih (Melaleuca cajuputi) Stands
}

\author{
Taufan Alam ${ }^{1 *}$, Priyono Suryanto ${ }^{2}$, Aprilia Ike Nurmalasari ${ }^{3}$ and Budiastuti Kurniasih ${ }^{1}$ \\ ${ }^{1}$ Department of Agronomy, Faculty of Agriculture, Universitas Gadjah Mada, Yogyakarta, Indonesia; \\ ${ }^{2}$ Department of Silviculture, Faculty of Forestry, Universitas Gadjah Mada, Yogyakarta, Indonesia; \\ ${ }^{3}$ Department of Agrotechnology, Faculty of Agriculture, Universitas Sebelas Maret, Surakarta, Indonesia
}

${ }^{*}$ Corresponding author: taufan.alam@ugm.ac.id

\begin{abstract}
The existence of genotype and environment ( $\mathrm{G} \times \mathrm{E}$ ) interaction causes difficulty in selecting suitable varieties of soybean in an agroforestry system based on kayu putih stands. This study aimed to determine the suitability of adaptive, stable and high yield soybean varieties in an agroforestry system based on kayu putih stands by using GGE-Biplot analysis. The experiment was conducted from May to August 2018 at Menggoran Forest Resort, Playen District, Gunungkidul Regency, Special Region of Yogyakarta, Indonesia. The experiment was conducted using a Randomized Complete Block Design (RCBD) with five block as replications. The first factor was soil type in Menggoran Forest Resort, consisting of Lithic Haplusterts, Ustic Epiaquerts and Vertic Haplustalfs. The second factor was soybean varieties, consisting of Anjasmoro, Argomulyo, Burangrang, Dering I, Devon I, Gema and Grobogan. The observation was carried out on seed dry weight of soybean per hectare. The data were analyzed using Combined Analysis of Variance (ANOVA) with $\alpha=5 \%$ and GGE-Biplot. Dering I was the most suitable varieties in an agroforestry system based on kayu putih stands and showed the mean of highest yield of 1.22 tons ha ${ }^{-1}$.
\end{abstract}

Keywords: agroforestry system, GGE-Biplot, kayu putih, soybean, suitability, varieties

Cite this as: Alam, T., Suryanto, P., Nurmalasari, A. I., \& Kurniasih, B. (2019). GGE-Biplot Analysis for the Suitability of Soybean Varieties in an Agroforestry System based on Kayu Putih (Melaleuca cajuputi) Stands. Caraka Tani: Journal of Sustainable Agriculture, 34(2), 213-222. doi: http://dx.doi.org/10.20961/carakatani. v34i2.30434

\section{INTRODUCTION}

Kayu putih (Melaleuca cajuputi) forest in Yogyakarta Indonesia Forest Management has a highly strategic role in contributing to LocallyGenerated Revenue of Special Region of Yogyakarta. It also provides life support to communities around the forest through intercropping for annual crops, such as rice, maize, soybean, peanut, cassava, etc., among kayu putih standing crop (Suryanto et al., 2013).

The space area between kayu putih is potential for the cultivation of annual crops. Soil productivity can be improved through the alley cropping system (Suryanto et al., 2017). The combination of kayu putih and annual crops provides benefits in sharing of resources such as nutrient, light and water so that soybean can get the advantages from these resources (Scholes and Walker, 1993; Ong and Huxley, 1996).

The width of kayu putih forest area that can be used for the development of annual crops is 4,603.72 hectare or 28\% of the Yogyakarta Forest Management District. This kayu putih forest is spread over five Forest Sections, namely Karangmojo Forest Section with an area of 2,267.6 hectare, Playen Forest Section with an area of 1,616.37 hectare, Paliyan Forest Section

\footnotetext{
* Received for publication May 30, 2019

Accepted after corrections August 20, 2019
} 
covering an area of 403.3 ha, Kulon Progo-Bantul Forest Section covering an area of 286.45 hectare and Panggang Forest Section covering 30 hectares (Yogyakarta Forest Management District, 2012).

Soybean is an oilseed crop in the world providing $58 \%$ of total global oilseed production (Board, 2013). Soybean is the leading commodity in Indonesia contributing to food security, which is often faced with constraint in its availability. Soybean production in 2015 in the Special Region of Yogyakarta, Indonesia, was 18.822 tons of dry beans or decreased by 757 tons $(3.87 \%)$, compared to the production in 2014 (Buana et al., 2016). The soybean production decreases by $15 \%$ in 2.451 ha harvested area. Thus, the existence of forests to guarantee the production of soybean is indispensable, one of which is by intercropping of kayu putih that is good for intercropping among soybean (Suryanto et al., 2017).

Introducing new varieties is one of the leading technologies that can increase rice productivity and farmers income. These new cultivars are also the most accessible technology adopted by farmers because they are low-priced and highly applicable (Zaini et al., 2016). Makarim and Las (2005) showed that in order to achieve maximum yield from new varieties, an appropriate growing environment is needed so that the yield and superiority can be improved.

Selection of varieties for yield stability across various environmental conditions is important as part of a breeding program to provide a recommendation for the best genotype across environments (Gauch, 2006; Piepho et al., 2016). This is focal to do before giving the recommendation of these cultivars to farmers (Piepho et al., 2016). In addition, selection of varieties that are well suited to the environment can maximize the yield potential of these varieties for reducing inputs (ex. fertilizer) and helping to build a sustainable production system (European Union, 2012).

Farmers will adopt excellent varieties if the varieties have high yields and stable crops. In adaptability and stability tests, the interaction between genotype and environment ( $\mathrm{G} \times \mathrm{E}$ ) often occurs and leads to difficulty in plant breeding program (Singh and Chaudary, 1979). G x E interaction causes tested genotype superiority shows different crop ability on each different environment characteristic. It indicates that the highest yield of a genotype on the specific environment does not necessarily contribute to the highest yield on different environment as well (Finlay and Wilkinson, 1963; Eberhart and Russell, 1966).

Evaluation relating to genotype varieties on various environmental conditions will be performed with several statistical methods, namely univariate parametric, univariate and multivariate methods in the parametric method. One of the varieties which grows rapidly is Genotype and Genotype by Environment Interaction Biplot (GGE-Biplot) (Yan et al., 2000). Graphic of GGE-biplot may give visual information relating to the evaluation on genotype, environment and its interaction (Yan et al., 2007).

This research aims to determine the suitability of adaptive, stable and high yield of soybean varieties in an agroforestry system with kayu putih. It will help to recommend forestry farmers relating to soybean varieties which are suitable to be cultivated in the kayu putih forest.

\section{MATERIALS AND METHOD}

The experiment was conducted at Menggoran Forest Resort, Playen District, Gunungkidul Regency, Special Region of Yogyakarta, Indonesia form May to August 2018. This area is located $\pm 43 \mathrm{~km}$ to the south-east of Yogyakarta. The soybean varieties were from Indonesian Legumes and Tuber Crops Research Institute in Malang Regency, East Java, Indonesia.

The testing was performed using a Randomized Complete Block Design (RCBD) with five blocks of replications. The first factor was the type of soil in Menggoran Forest Resort consisting of Lithic Haplusterts, Ustic Epiaquerts and Vertic Haplustalfs. The second factor was soybean varieties, consisting of Anjasmoro, Argomulyo, Burangrang, Dering I, Devon I, Gema and Grobogan. The experiment plot was placed between kayu putih stands, $4 \mathrm{~m} \mathrm{x} 4 \mathrm{~m}$ in size. The plant spacing of soybean was $40 \mathrm{~cm} \mathrm{x}$ $20 \mathrm{~cm}$. Fertilization was not carried out during the study according to the habits of farmers. The observation of soybean yield was conducted on the seed dry weight. Soybean seeds were dried under the sunlight to the $11 \%$ of moisture level.

The models must be evaluated so that assumptions can be fulfilled. The normality test in this study was carried out using Kolmogorov test and Q-Q plot (Mocada et al., 2014). Data on the yield of soybean varieties were subjected to be 
analyzed using Combined Analysis of Variance (ANOVA) to determine the effects of soil types $(\mathrm{E})$, soybean varieties $(\mathrm{G})$ and their interactions (GE). The result of Combined ANOVA was then examined with HSD-Tukey test $\alpha=5 \%$. Combined ANOVA and HSD-Tukey test $\alpha=5 \%$ were performed using PROC MIXED in SAS 9.4 (SAS Institute, 2013).

The data were graphically analyzed for interpreting GE interaction using the GGE-biplot software (Yan, 2001). GGE-Biplot analysis, which consisted of two concepts, the biplot concept (Gabriel, 1971) and the GGE concept (Yan et al., 2000), was employed to visually analyze the soybean in each soil type trial. This methodology used a biplot to show the factors $(G$ and GE), which are important in soybean evaluation and the sources of variation in GE interaction analysis of data on soil types (Yan, 2001). The graphs were generated based on which-won-where pattern, average environment coordination (AEC) and genotype focused scaling pattern based on the angles between the vectors of the soil types. The GGE-Biplot graph was completed using GGE-Biplot software version 7.0 (Yan and Tinker, 2006).

\section{RESULTS AND DISCUSSION}

\section{Characteristics of locations}

The study site had an ustic soil moisture regime. It was a soil moisture regime that had limited water content but was suitable for plant growth when conditions were favorable (Boettinger et al., 2015). The altitude of the study site varied from 100-200 meters above sea level. The air temperature ranged between $24.80^{\circ} \mathrm{C}$ and $26.40^{\circ} \mathrm{C}$. The relative humidity ranged between $81.90 \%$ and $86.50 \%$. The total rainfall in the study area was $2,005 \mathrm{~mm}$ year ${ }^{-1}$.

Lithic Haplusterts belongs to the Vertisol soil type which has a shallow solum and rock or lithic contact within $50 \mathrm{~cm}$ from the surface and has an ustic soil moisture regime (Soil Survey Staff, 2014). Cracked soil may happen throughout the season when the soil is not adequately irrigation. The cracks extend through $>5 \mathrm{~mm}$ wide and $>25$ $\mathrm{cm}$ of the upper $50 \mathrm{~cm}$ (Boettinger et al., 2015). Vertic Hapustalfs belongs to Alfisol soil type which has a clay accumulation (argillic sub-soil horizon) with a decrease in clay content within a depth of $150 \mathrm{~cm}$ and has an ustic soil moisture regime (Soil Survey Staff, 2014). The Alfisol soil type has vertic characteristic. It has a $5 \mathrm{~mm}$ width fracture $>60 \mathrm{~cm}$ from the soil surface (Boettinger et al., 2015). Ustic Epiaquerts is Vertisol soil type which has $>5 \mathrm{~mm}$ fracture and $>25 \mathrm{~cm}$ thickness for 90 days in each year in a reasonable condition when it is not irrigated and has an ustic soil moisture regime (Soil Survey Staff, 2014).

\section{Soybean varieties performance in different soil types}

The Combined ANOVA indicates that the soybean varieties $(\mathrm{G})$, soil types $(\mathrm{E})$ and $\mathrm{G} \times \mathrm{E}$ interaction variance were highly significant. The highly significant $\mathrm{G} \times \mathrm{E}$ effects suggest that genotypes may be selected for adaptation to specific environments (Aina et al., 2009).

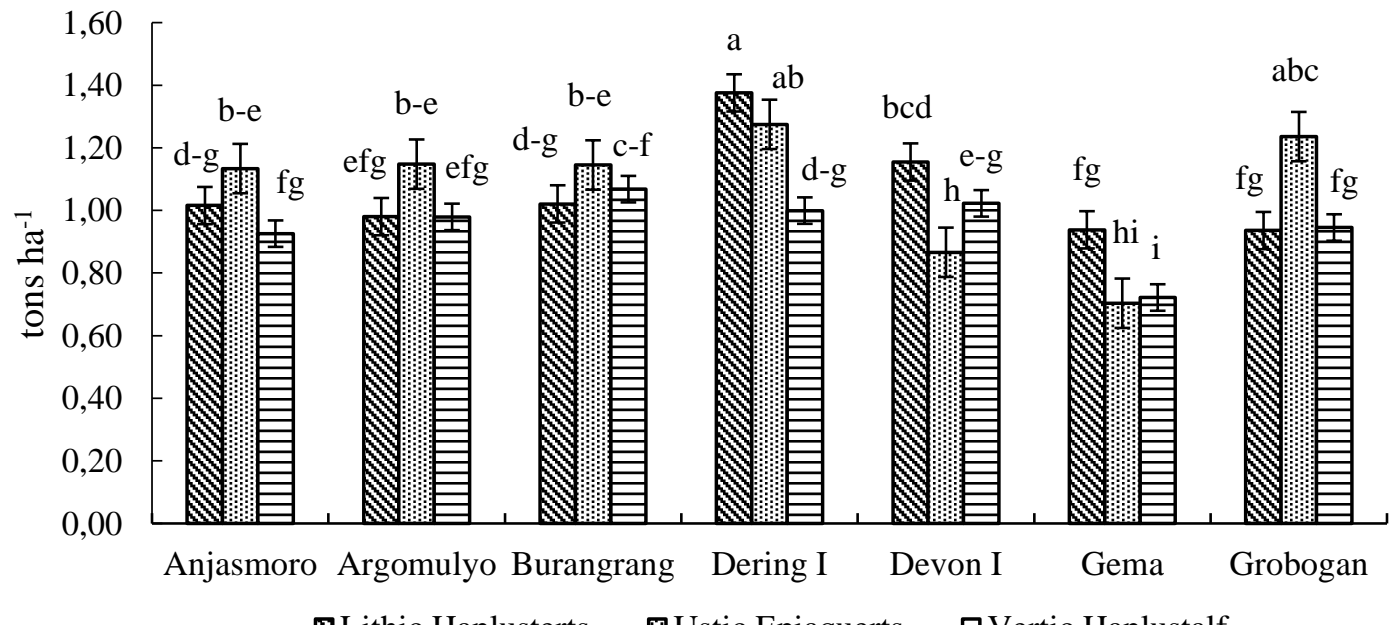

ه Lithic Haplusterts 国Ustic Epiaquerts $\quad$ V Vertic Haplustalf

The same letters show there is not any significant difference with HSD Tukey test $\alpha=5 \%$.

Figure 1. Yield of soybean varieties per hectare in different soil types. 
Dering I had the highest seed weight when it was planted in Lithic Haplusterts and Ustic Epiaquerts, obtaining 1.38 and 1.27 tons $\mathrm{ha}^{-1}$ respectively (Figure 1), on the other hand, Grobogan produced seed with the highest seed weight of 1.24 tons ha $^{-1}$ on in Vertic Haplustalfs (Figure 1). Giller et al. (2011) suggested that each plant had a different response in absorbing nutrients, fertilizers and lime applications in a site. This suggests that soil has a high heterogeneity that affects plant growth.

The highest result on each environment (soil types) had not reflected such varieties adaptive and stable for all soil types. It was because of the existence of $\mathrm{G} \times \mathrm{E}$ interaction. It is consistent with the research by Xu et al. (2014) showing that $G \times$ $E$ interaction effects demonstrate that genotypes respond differently to the variation in environmental conditions of the locations, indicating the necessity of testing rice varieties at multiple locations.
The suitability of soybean varieties for agroforestry system based on kayu putih stands

The suitability of soybean varieties can be identified with adaptability and stability analysis using GGE-Biplot method. Figure 2 presents the straight line from biplot point vertically across the connection on each side and divides biplot varieties into six quadrants or sectors, in which each sector has genotype vertex. It results in four sectors. Two sectors contain environment and the rest two sectors do not contain environment. The sectors which contain environment are megaenvironments (Mega-E) (Yan and Kang, 2003). The GGE-biplot showed that the first two principal components (PC1 and PC2, also referred to as primary and secondary effects, respectively) were derived from subjecting environmentcentered yield data (yield variation due to GGE) to singular value decomposition (Yan et al., 2000).

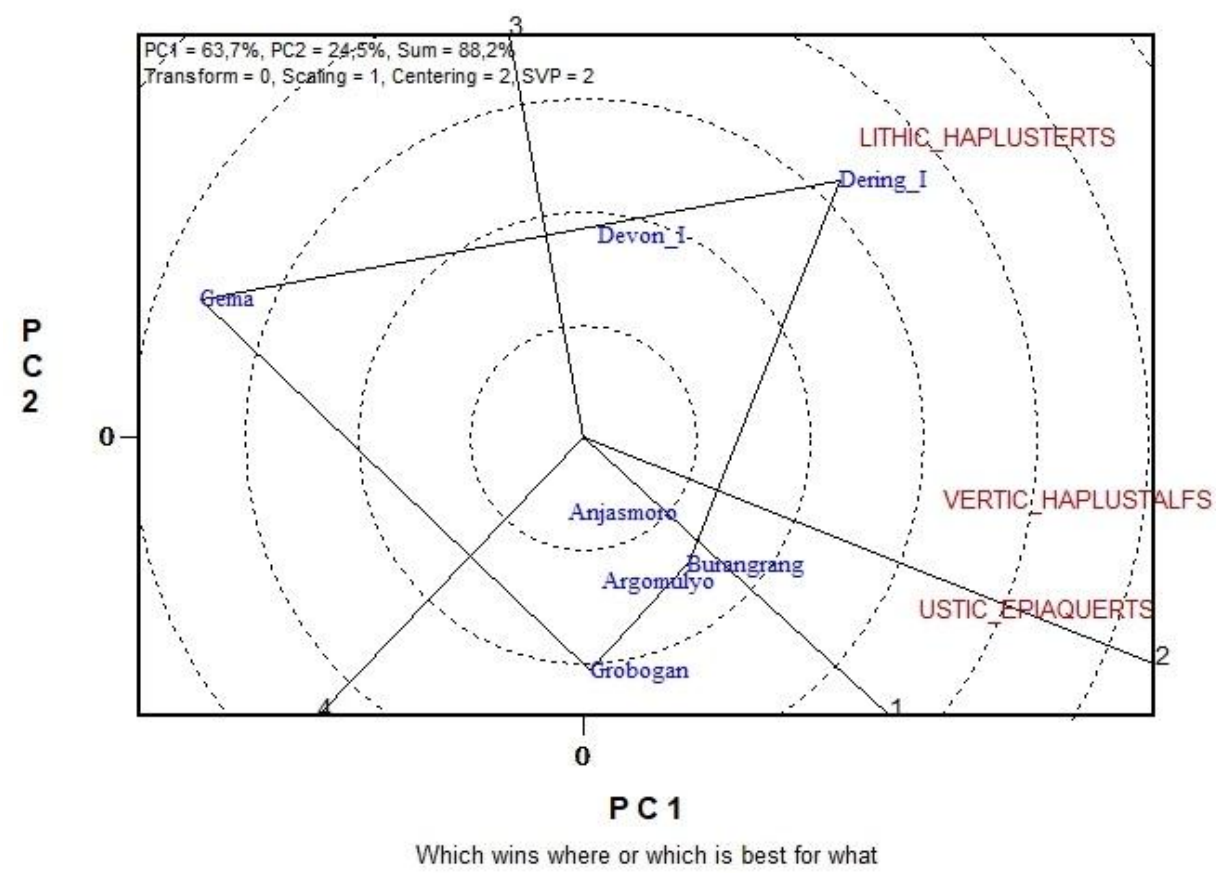

Figure 2. GGE-Biplot poligon with which-wons-where pattern on varieties and environment

Within the sector, there is genotype vertex, which is the most exterior genotype and if it is connected with the connection line, it will form polygon (Farshadfar et al., 2013). The Genotype vertices in Figure 2 were Dering I, Burangrang, Grobogan and Gema. These genotypes were the best or the poorest genotypes on several or all environments. This is because of the farthest distance of genotype from biplot point. Genotype vertex is the best genotype on the environment in the same vector so that each genotype vertex is a genotype which has the best local adaptation on each Mega-E (Yan and Kang, 2003).

Mega-E is defined as an environment that is widely formed from environments with the same character. Figure 2 presents that there are two 
Mega-E, with three testing locations, Lithic Haplusterts, Ustic Epiaquerts and Vertic Haplustalfs. The vertex Dering I varieties was high yielding for Lithic Haplusterts and Vertic Haplustalfs and this varieties falls into section 1, following Devon I. Other three vertices, Burangrang, Grobogan and Gema, produced medium-high yield and poor yield with poor adaptation to three testing soil types. These genotypes are the best or the poorest in several or all environments because they are the farthest from the origin of biplot (Yan and Kang, 2003) and are more responsive to environmental change and are considered as specially adapted genotypes.
The varieties and stability of genotype may be evaluated with a mean environment coordinate (AEC) method (Yan, 2001). Figure 3 with one arrow passes the central point of the environment (the origin point of biplot) is AEC abscissa, which depicts the mean value of varieties for all soil types. Small circle within AEC line is the mean of soil types (Figure 3 ). The arrow direction of AEC abscissa is pulled passing biplot origin point and the mean of soil types. Meanwhile, the vertical line from AEC abscissa is AEC ordinate (Kaya et al., 2006). AEC abscissa follows the arrow direction and it shows the more significant main effect of genotype (Yan, 2001). The ordinate of AEC is marked by two arrows (Figure 3).

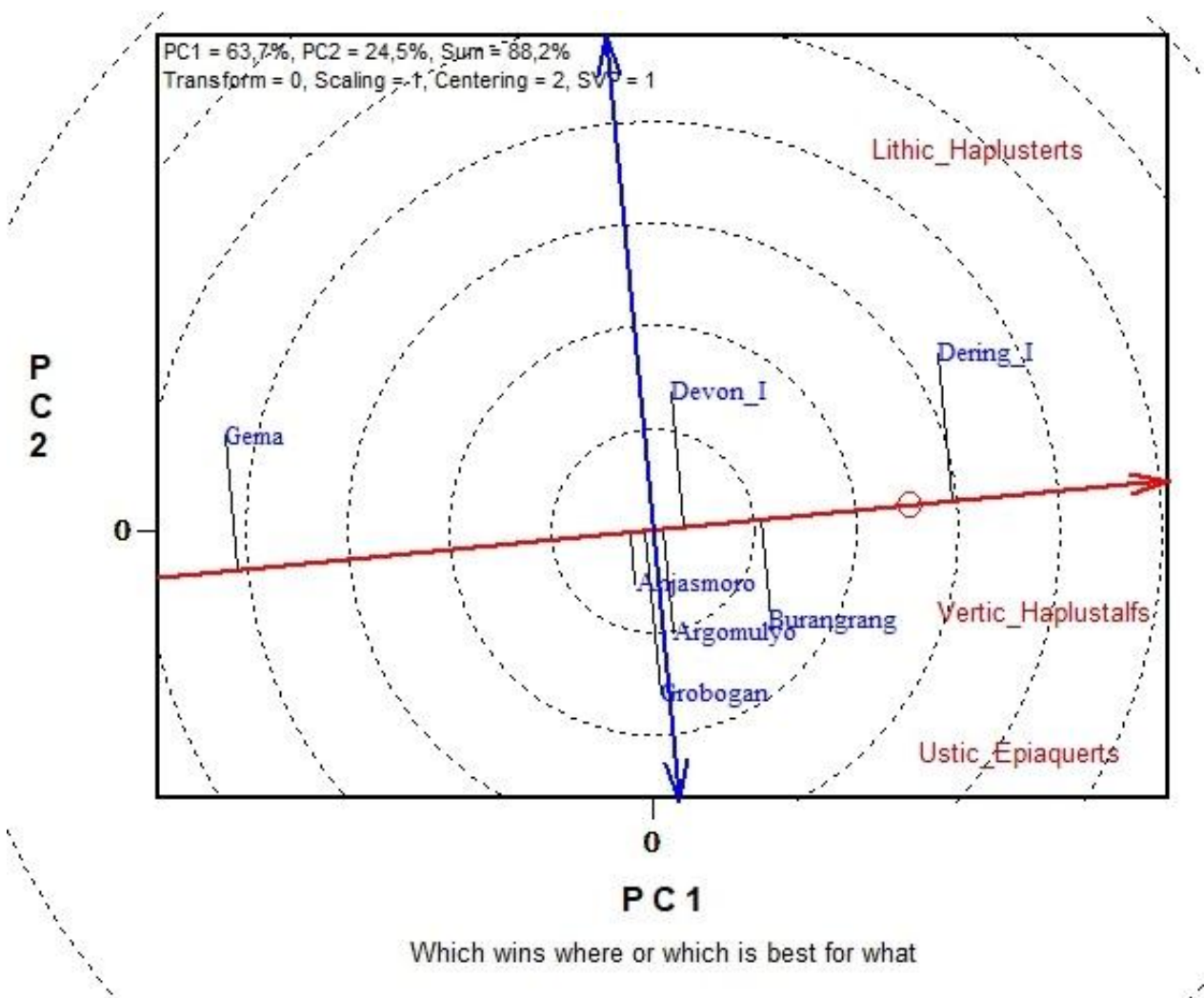

Figure 3. Average environment coordination (AEC) shows GGE-biplot based on environmentfocused scaling of the mean value and stability of genotype.

AEC ordinate shows tested varieties of stability. If varieties vector is far from biplot origin value, $\mathrm{G} \times \mathrm{E}$ effect would be more significant and reduce stability. AEC ordinate also divides genotype with high and poor yield (Figure 3). Dering I and Devon I varieties have higher stability as well as higher yield while the Devon I has the highest stability out of these two varieties. According to Yan and Rajcan (2002), the ideal genotype is genotype with big PC1 score (high mean value) and small PC2 absolute score (high stability).

The ideal genotype is genotype with high mean value and stability. Ideal genotype does not truly exist, but it can be used as a recommendation to evaluate a genotype. In Figure 4, there is the center of the concentric circle where ideal genotype (highest yield and most stable) must be placed (Karimizadeh et al., 2013). Ideal genotypes are in the first concentric circle. The desired 
genotype is in the second concentric circle. Genotypes which are in third concentric and the next ones are less desired since they have poor yielding (Kaya et al., 2006).

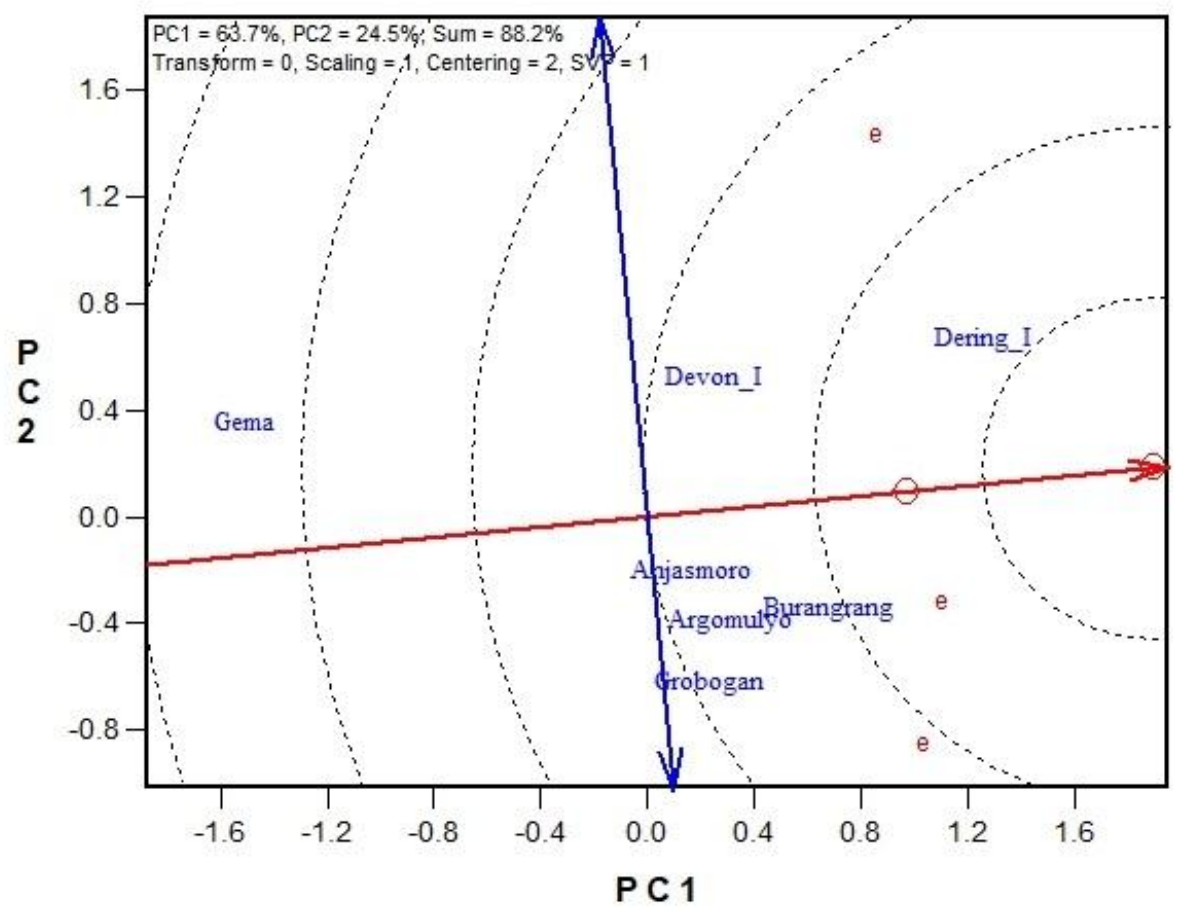

Ranking entries based on both Mean and Instability

Figure 4. GGE-biplot based on genotype-focused scaling to compare genotype with ideal genotype

In Figure 4, none of the varieties is included as ideal genotype. Dering I belongs to desired genotype, while Burangrang, Devon I and Argomulyo are not very good. Grobogan and Anjasmoro are included as low quality genotype and Gema, according to genotype classification by Yan and Tinker (2006) goes to the worst genotype so that it will generate poor crop in all testing locations.

Dering I in general shows the most suitable varieties in agroforestry with kayu putih with mean value amounting to 1.22 ton ha ${ }^{-1}$. Different yield of soybean on each location can be related to nutrient content of three soil types of testing locations. Alam and Kurniasih (2018) informed that varieties of Dering I is negatively correlated with $\mathrm{Mn}$, while other varieties generally have positive correlation with $\mathrm{NH}_{4}{ }^{+}$and $\mathrm{P}$ and have negative correlation with $\mathrm{Mg}$. Three types of soil in the testing location have $\mathrm{NH}_{4}{ }^{+}, \mathrm{P}$ and $\mathrm{Mn}$ contents in the low category and $\mathrm{Mg}$ content in very high category.

Dering I can be adaptive and stable because three types of soil in the location of the research have low Mn content. The yield of Dering I decrease in line with the increasing availability of Mn in the soil. Silva et al. (2017) reported that Mn poison in maize may reduce chlorophyll content, plant biomass and plant antioxidants.

Other varieties are not adaptive and stable since $\mathrm{NH}_{4}{ }^{+}$and $\mathrm{P}$ contents in the location fall into low category and $\mathrm{Mg}$ content is in the high category. $\mathrm{N}$ is a macronutrient needed for plant growth although $\mathrm{N}$ compounds (i.e., $\mathrm{NH}_{4}^{+}, \mathrm{NO}_{2}{ }^{-}$ and $\mathrm{NO}_{3}{ }^{-}$) contribute $<5 \%$ of total $\mathrm{N}$ in the soil (Brady and Weil, 2008). Nitrogen can be a limiting factor for plant growth, after fixed carbon (Marschner and Marschner, 2012). In physiology process, urea is an essential internal and external source of $\mathrm{N}$, which is converted into ammonia for $\mathrm{N}$ assimilation (Wang et al., 2008).

Soybean is one of the leguminous plants that require $\mathrm{P}$ higher than other types do. $\mathrm{P}$ is an important macronutrient which has an important role in the growth and development of plant (Vance, 2001; Wang et al., 2008). Soybean requires the element $\mathrm{P}$ as energy for nitrogen fixation (Rotaru et al., 2014). Phosphorus deficiency in legumes causes a reduction in leaf area, decreases the number of leaves, nodes and 
branches and thus, yield decreases (Chaudhary et al., 2008).

Magnesium is the chlorophyll molecule component and it functions as a cofactor in enzyme activation in the phosphorylation process as a bridge between the pyrophosphate structure of ATP or ADP and enzyme molecules (Katalin, 2011). The high concentration of $\mathrm{Mg}^{2+}$ in the cytoplasm can block the $\mathrm{K}^{+}$channel in the inner envelope membrane of the chloroplasts and thus, inhibit the removal of $\mathrm{H}^{+}$ions from the chloroplast stroma. This causes acidification of the stroma and then it inactivates important enzymes in carbon fixation (Venkatesan and Jayaganesh, 2010).

\section{CONCLUSIONS}

Soybean varieties show different yields per hectare when planted in Lithic Haplusterts, Vertic Haplustalfs and Ustic Epiaquerts. Dering I and Devon I varieties have higher stability as well as higher mean of yield and Burangrang, Grobogan and Gema gave medium-high yield and poor yield with poor adaptation. Dering I is the most suitable varieties in agroforestry system based on kayu putih stands and shows the mean of highest yield of 1.22 tons ha" ${ }^{-1}$.

\section{ACKNOWLEDGEMENT}

The authors would like to thank the Directorate of Research, Universitas Gadjah Mada, which has funded this research through the University grantin-aid scheme (No: 3129/UN1/DITLIT/DIT-LIT/ LT/2018).

\section{REFERENCES}

Aina, O. O., Dixon, A. G. O., Paul, I., \& Akinrinde, E. A. (2009). G×E Interaction Effects on Yield and Yield Components of Cassava (Landraces and Improved) Genotypes in The Savanna Regions of Nigeria. African Journal of Biotechnology, 8(19), 4933-4945. Retrieved from https://www.ajol.info/index. php/ajb/article/view/65189

Alam, T., \& Kurniasih, B. (2018). Determination of Soil Quality Minimum Data Set (MDS) as The Basis for Sustainable Management of Soybean Agroforestry System with Kayu Putih in Yogyakarta. Yogyakarta, Indonesia: Young Lecturer Research Report, Universitas Gadjah Mada.
Board, J. E. (2013) Preface in A Comprehensive Survey of International Soybean Research Genetics, Physiology, Agronomy and Nitrogen Relationships. InTech. Rijeka, Croatia.

Boettinger, J., Chiaretti, J., Ditzler, C., Galbraith, J., Kerschen, K., Loerch, C., McDanie P., McVey, S., Monger, C., Owens, P., Ransom, M., Scheffe, K., Shaw, J., Stolt, M., \& Weindorf, D. (2015). Illustrated Guide to Soil Taxonomy. $2^{\text {nd }}$ ed. Lincoln, Nebraska, USA: U.S. Department of Agriculture, Natural Resources Conservation Service, National Soil Survey Center. Retrieved from https://www. nrcs.usda.gov/wps/PA_NRCSConsumption/d ownload/?cid=stelprdb1247203.pdf

Brady, N. C., \& Weil, R. R. (2008). Soil Colloids: Seat of Soil Chemical and Physical Acidity. Upper Saddle River, NJ, USA: Pearson Education Inc. Retrieved from https://www. researchgate.net/publication/309630422_Soil _colloids_Seat_of_soil_chemical_and_physic al_acidity

Buana, W. P., Hariyanto, Iswadi, Poerwaningsih, R., Drajat, D., Hartini, M., Amalia, R. R., Fitrianingrum, V., Kadir, Siagian, S. H., Lestari, N. G. P. A., Prasetyo, O. R. (2016). Production of Food Crops 2015. Indonesia: BPS-Statistic. Retrieved from https://www. bps.go.id/publication/2016/09/26/b5a5f1072f ea10fcf5fa80c4/produksi-tanaman-pangan2015.html

Chaudhary, M. I., Gyamfi, J. A., Saneoka, H., Nt, N., Suwa, R., Kanai, S., El-Shemy, H., Lightfoot, D. A., \& Fujita, K. (2008). The Effect of Phosphorus Deficiency on Nutrient Uptake, Nitrogen Fixation and Photosynthetic Rate in Mashbean, Mungbean and Soybean. Acta Physiologiae Plantarum, 30(4), 537-544. https://doi.org/10.1007/s11738-008-0152-8

Eberhart, S. A., \& Russell, W. A. (1966). Stability Parameters for Comparing Varieties. Crop Science, 6, 36-40. https://doi.org/10.2135/ cropsci1966.0011183X000600010011x

European Union. (2012). Sustainable Agriculture for The Future We Want. Brussels, Belgium: International Cooperation and Development, European Commission. Retrieved from https://ec.europa.eu/agriculture/sites/agricultu re/files/events/2012/rio-side-event/brochure_ en.pdf 
Farshadfar, E., Hassan Z., \& Reza, M. (2013). Evaluation of Phenotypic Stability in Chickpea Genotypes using GGE-Biplot. Annals of Biological Research, 2, 282-292. Retrieved from https://pdfs.semanticscholar.org/0dcd/25 992bcdadd46a58f4766452024b959493fd.pdf? _ga=2.25715261.1841181295.15692292111426819582.1560504050

Finlay, K. W., \& Wilkinson, G. N. (1963). The Analysis of Adaptation in a Plant Breeding Programme. Australian Journal of Agri cultural Research, 14(6), 742-754. https:// doi.org/10.1071/AR9630742

Gabriel, K. R. (1971). The Biplot Graphic Display of Matrices with Application to Principal Component Analysis. Biometrica, 58, 453467. https://doi.org/10.1093/biomet/58.3.45 3

Gauch, H. G. (2006). Statistical Analysis of Yield Trials by AMMI and GGE. Crop Science, 46(4), 1488-1500. https://doi.org/10.2135/ cropsci2005.07-0193

Giller, K. E., Tittonell, P., Rufino, M. C., van Wijk, M. T., Zingore, S., Mapfumo, P., Adjeinsiah, S., Herrero, M., Chikowo, R., Corbeels, M., Rowe, E. C., Baijukya, F., Mwijage, A., Smith, J., Yeboah, E., van der Burg, W. J., Sanogo, O. M., Misiko, M., de Ridder, N., Karanja, S., Kaizzi, C., K'ungu, J., Mwale, M., Nwaga, D., Pacini, C., \& Vanlauwe, B. (2011). Communicating Complexity: Integrated Assessment of TradeOffs Concerning Soil Fertility Management within African Farming System to Support Innovation and Development. Agricultural Systems, 104(2), 191-203. https://doi.org/10. 1016/j.agsy.2010.07.002

Karimizadeh, R., Mohammadi, M., Sabaghni, N., Mahmoodi, A. A., Roustami, B., Seyyedi, F., \& Akbari, F. (2013). GGE Biplot Analysis of Yield Stability in Multi-Environment Trials of Lentil Genotypes under Rainfed Condition. Notulae Scientia Biologicae, 5(2), 256-262. https://doi.org/10.15835/nsb529067

Katalin, S. (2011). Nutrient Management. Egyetem: University of Pannonia. Retrieved from https://www.tankonyvtar.hu/en/tartalom /tamop425/0010_1A_Book_angol_02_tapany aggazdalkodas/index.html
Kaya, Y., Akcura, M., \& Taner, S. (2006). GGEBiplot Analysis of Multi-Environment Yield Trials in Bread Wheat. Turkish Journal of Agriculture and Forestry, 30, 325-337. Retrieved from https://journals.tubitak.gov.tr/ agriculture/abstract.htm?id=8495

Makarim, A. K., \& Las, I. (2005). Breakthrough in Increasing Productivity of Irrigated Rice Through the Development of Integrated Crop and Resource Management Models. Indonesia: Indonesia Agency for Agricultural Research and Development, Ministry of Agriculture. Retrieved from http://perpustakaan.pertanian. go.id/repository_litbang/repository/artikel/0/0 /2005/0/5362

Marschner, H., \& Marschner, P. (2012). Marschner's Mineral Nutrition of Higher Plants. $3^{\text {rd }}$ ed. London, United Kingdom: Academic Press. https://doi.org/10.1016/C20 09-0-63043-9

Mocanda, M. P., Gabriels, D., \& Cornelis, W. M. (2014). Data-Driven Analysis of Soil Quality Parameters using Limited Data. Geoderma, 235-236, 271-278. https://doi.org/10.1016/j. geoderma.2014.07.014

Ong, C. K., \& Huxley, P. A. (1996). Tree-Crop Interactions: A Physiological Approach. Wallingford, United Kingdom: CAB International in association with The International Centre for Research in Agroforestry. Retrieved from http://www.gbv. de/dms/goettingen/215805399.pdf

Piepho, H. P., Nazir, M. F., Qamar, M., Rattu, A. U. R., Din, R. U., Hussain, M., Ahmad, G., Subhan, F. E., Ahmad, J., Abdullah, Laghari, K. B., Vistro, I. A., Kakar, M. S., Sial, M. A., \& Imtiaz, M. (2016). Stability Analysis for a Countrywide Series of Wheat Trials in Pakistan. Crop Science, 56, 2465-2475. https: //doi.org/10.2135/cropsci2015.12.0743

Rotaru, V., Toma, S., \& Birsan, A. (2014). The Effects of Phosphorus Deficiency and Rhizobacteria on Phosphorus Contents of Two Soybean (Glycine max L.) Cultivars Grown at Low Water Supply. Scientific Papers Series A. Agronomy, 70, 316-321. Retrieved from https://pdfs.semanticscholar.org/4f11/5feb4ba b8b553a0f533407b5994d996a4ac0.pdf 
SAS Institute Inc. (2013). Base SAS ${ }^{\circledR}$ 9.4. Procedures Guide: Statistical Procedures. $2^{\text {nd }}$ ed, NC, USA: SAS Institute Inc., Cary. Retrieved from https://support.sas.com/docu mentation/cdl/en/procstat/66703/HTML/defau lt/viewer.htm

Scholes, R. J., \& Walker, B. H. (1993). An African Savanna: Synthesis of The Nylsvley Study. New York, USA: Cambridge University Press.

Silva, D. D., Fonte, N. D. S. D., Souza, K. R. D. D., Brandão, I. R., Libeck, I. T., \& Alves, J. D. (2017). Relationship between Manganese Toxicity and Waterlogging Tolerance in Zea mays L. cv. Saracura. Acta Scientiarum Agronomy, 39(1), 75-82. https://dx.doi.org/ 10.4025/actasciagron.v39i1.30997.

Singh, R. K., \& Chaudhary, B. D. (1979). Biometrical Method in Quantitative Genetic Analysis. New Delhi: Kalyani Publisher.

Soil Survey Staff. (2014). Key to Soil Taxonomy. $2^{\text {nd }}$ ed. Lincoln, Nebraska, USA: U.S. Department of Agriculture, Natural Resources Conservation Service, National Soil Survey Center. Retrieved from https://www.nrcs.usda. gov/wps/portal/nrcs/detail/soils/survey/class/t axonomy/?cid=nrcs142p2_053580

Suryanto, P., Tohari, Sulistyaningsih, E., Putra, E. T. S., Kastono, D., \& Alam, T. (2017) Estimation of Critical Period for Weed Control in Soybean on Agroforestry System with Kayu Putih. Asian Journal of Crop Science, 9(3), 8291. http://dx.doi.org/10.3923/ajcs.2017.82.91

Suryanto, P., Widiyatno, Sukirno, D. P., Dwiko, B. P., \& Agus, A. (2013). Compatibility of Private Agroforestry Management and Managing Forest with Community Program in Central Java, Indonesia. Journal of Management and Sustainability, 3(1), 178185. https://doi.org/10.5539/jms.v3n1p178

Vance, C. P. (2001). Symbiotic Nitrogen Fixation and Phosphorus Acquisition: Plant Nutrition in a World of Declining Renewable Resources. Plant Physiology, 127(2), 390-397. Retrieved from https://www.ncbi.nlm.nih.gov/pmc/arti cles/PMC1540145/

Venkatesan, S., \& Jayaganesh, S. (2010). Charac terisation of Magnesium Toxicity, Its Influence on Amino Acid Synthesis Pathway and Biochemical Parameters of Tea. Research
Journal of Phytochemistry, 4, 67-77. http://dx. doi.org/10.3923/rjphyto.2010.67.77

Wang, W. H., Kohler, B., Cao, F. Q., \& Liu, L. H. (2008). Molecular and Physiological Aspects of Urea Transport in Higher Plants. Plant Science, 175(4), 467-477. https://doi.org/10. 1016/j.plantsci.2008.05.018

Xu, F. F., Tang, F. F., Shao, Y. F., Chen, Y. L., Tong, C., \& Bao, J. S. (2014). Genotype $\times$ Environment Interaction for Agronomic Traits of Rice Revealed by Association Mapping. Rice Science, 21(3), 133-141. https://doi.org/ 10.1016/S1672-6308(13)60179-1

Yan, W. (2001). GGE Biplot a Windows Application for Graphical Analysis of MultiEnvironment Trial Data and other Types of Two-Way Data. Agronomy Journal, 93(5), 1111-1118. https://doi.org/10.2134/agronj200 $1.9351111 \mathrm{x}$

Yan, W., \& Kang, M. S. (2003). GGE Biplot Analysis: A Graphical Tool for Breeders, Geneticists and Agronomists. $1^{\text {st }}$ Edn, Boca Raton, Florida: CRC Press LLC. https:// doi.org/10.1201/9781420040371

Yan, W., \& Racjan, I. (2002). Biplot Analysis of Test Site and Trait Relations of Soybean in Ontario. Crop Science, 42(1), 11-20. https:// doi.org/10.2135/cropsci2002.1100

Yan, W., \& Tinker, N. A. (2006). Biplot Analysis of Multi-Environment Trial Data: Principles and Applications. Canadian Journal of Plant Science, 86(3), 623-645. https://doi.org/10.41 41/P05-169

Yan, W., Hunt, L. A. Sheng, Q., \& Szlavnics, Z. (2000). Cultivar Evaluation and MegaEnvironment Investigation Based on GGE Biplot. Crop Science, 40(3), 507-605. https:// doi.org/10.2135/cropsci2000.403597x

Yan, W., Kang, M. S., Ma, B., Woods, S., \& Cornelius, P. L. (2007). GGE-Biplot vs. AMMI Analysis of Genotype-by-Environment Data. Crop Science, 47(2), 643-655. https:// doi.org/10.2135/cropsci2006.06.0374

Yogyakarta Forest Management District. (2012). Forest Management in Yogyakarta Forest Management District Institute. Special Region of Yogyakarta, Indonesia: Department of Forestry and Plantation. Retrieved from 
http://kph.menlhk.go.id/index.php?option=co m_content \&view=article\&id=91:profil $-\mathrm{kphp}-$ model-yogyakarta-\&catid=132: di-yogyakarta \&Itemid=353

Zaini, Z., Abdurrahman, S., Widiarta, N., Wardana, P., Setyorini, D., Kartaatmadja, S.,
\& Yamin, M. (2016). Integrated of Crop Management for Irrigated Rice Fields. Indonesia: Indonesia Agency for Agricultural Research and Development, Ministry of Agriculture. Retrieved from http://pangan. litbang.pertanian.go.id/files/pedumpajale/pttp adisawah.pdf 